\title{
Pulmonary exposure to diesel exhaust particles enhances fatty change of the liver in obese diabetic mice
}

\author{
MAKOTO TOMARU ${ }^{1,2}$, HIROHISA TAKANO ${ }^{2,3}$, KEN-ICHIRO INOUE ${ }^{2,3}$, RIE YANAGISAWA ${ }^{2}$, \\ NAOMI OSAKABE ${ }^{4}$, AKIKO YASUDA ${ }^{4}$, AKINORI SHIMADA ${ }^{5}$, YOJI KATO ${ }^{6}$ and HIROSHI UEMATSU ${ }^{1}$ \\ ${ }^{1}$ Gerodontology, Department of Gerodontology, Division of Gerontology and Gerodontology, Graduate School, \\ Tokyo Medical and Dental University, Tokyo; ${ }^{2}$ Environmental Health Sciences Division, National Institute for \\ Environmental Studies, Ibaraki; ${ }^{3}$ Inflammation and Immunology, Graduate School of Medical Science, \\ Kyoto Prefectural University of Medicine, Kyoto; ${ }^{4}$ Functional Foods Evaluation Group, Food and Health \\ R\&D Laboratories, Meiji Seika Kaisha, Ltd., Saitama; ${ }^{5}$ Department of Veterinary Pathology, Faculty of Agriculture, \\ Tottori University, Tottori; ${ }^{6}$ School of Human Science and Environment, University of Hyogo, Hyogo, Japan
}

Received June 13, 2006; Accepted August 18, 2006

\begin{abstract}
In epidemiological studies, exposure to ambient particulate matter (PM) has been reported to be positively associated with mortality in subjects with diabetes mellitus. Diesel exhaust particles (DEP) are major constituents of atmospheric PM. However, there is no experimental evidence for the relation of DEP to diabetes mellitus and its complications. We investigated the effects of DEP inoculated intratracheally on diabetic changes and nonalcoholic fatty liver disease (NAFLD) in diabetic obese and control mice. $\mathrm{db} / \mathrm{db}$ mice and the corresponding nondiabetic $\mathrm{db} /+\mathrm{m}$ mice received exposure to vehicle or DEP every two weeks. Animals were examined with biochemistry, histology, and immunohistochemistry for hexanoyl-lysine (HEL) in the liver. In the $\mathrm{db} /+\mathrm{m}$ mice, pulmonary exposure to DEP did not increase levels of aspartate aminotransferase (AST) or alanine aminotransferase (ALT) compared to that to vehicle. In the $\mathrm{db} / \mathrm{db}$ mice, however, the exposure to DEP increased the levels of AST and ALT compared to that to vehicle. Only in the $\mathrm{db} / \mathrm{db}$ mice, DEP enhanced the magnitude of steatosis and formation of HEL, a marker of oxidative stress, in the liver compared to vehicle. These results suggest that pulmonary exposure to DEP, PM, enhances steatosis in the liver of obese diabetic subjects possibly via enhanced oxidative stress.
\end{abstract}

\section{Introduction}

Previous epidemiological studies have demonstrated that exposure to ambient particulate matter (PM) is positively

Correspondence to: Dr Hirohisa Takano, Environmental Health Sciences Division, National Institute for Environmental Studies, 16-2 Onogawa, Tsukuba 305-8506, Japan

E-mail: htakano@nies.go.jp

Key words: particulate matter, diesel exhaust particles, reactive oxygen species, cytochrome P450, nonalcoholic fatty liver disease associated with increases in the morbidity and daily mortality caused by diseases, including ischemic heart disease $(1,2)$ and chronic obstructive pulmonary disease $(3,4)$, which are closely related to life habits. Diabetes mellitus and its complications are the other typical diseases related to life habits. Over the past several decades, prevalence of type 2 diabetes mellitus has reached epidemic levels in Western countries (5), which is a significant public health interest. The prognosis of patients with diabetes mellitus is worsened generally by a variety of complications including macro- or micro-angiopathy (6), fatty liver (7-10), nephropathy and infection in the presence or absence of obesity. Recent epidemiological studies have reported a positive association between mortality in patients with diabetes mellitus and ambient levels of PM $(11,12)$.

Air pollutants expelled from diesel engine-powered automobiles include diesel exhaust particles (DEP), which are known to be major constituents of atmospheric PM in metropolitan areas. DEP generate reactive oxygen species (ROS) (13) through a nonenzymatic process (14) or enzymatic reactions catalyzed by cytochrome P-450 (Cyp) (15). Furthermore, DEP enhance the gene expression for Cyp enzymes (15). DEP induce a variety of biological damage at least partly through oxidative stress (15).

Oxidative stress resulting from the imbalance between the production of ROS and the activity of antioxidative defense is implicated in the pathogenesis of diabetic complications by the ability to directly oxidize and damage protein, lipid, and DNA. In addition, Cyp enzymes, biological sources of ROS, are typically localized in the liver $(16,17)$. Therefore, it is possible that DEP exposure aggravates diabetic complications or liver diseases possibly through oxidative stress. However, there is little experimental evidence for the association between DEP exposure and the enhancement of fatty liver disease in diabetes mellitus.

The present study was designed to determine the enhancing effects of pulmonary exposure to DEP on nonalcoholic fatty liver disease (NAFLD), a most common chronic liver disease (18) in Western countries, using diabetic mice with obesity. We also examined the role of oxidative stress in the enhancement. 
Table I. Biochemical parameters in the plasma.

\begin{tabular}{|c|c|c|c|c|c|}
\hline & \multirow[b]{2}{*}{ Age (weeks) } & \multicolumn{2}{|c|}{$\mathrm{db} /+\mathrm{m}$} & \multicolumn{2}{|c|}{$\mathrm{db} / \mathrm{db}$} \\
\hline & & Vehicle & DEP & Vehicle & DEP \\
\hline Glucose (mg/dl) & $\begin{array}{l}18 \\
24\end{array}$ & $\begin{array}{l}261.5 \pm 60.0 \\
192.3 \pm 32.5\end{array}$ & $\begin{array}{r}190.5 \pm 10.9 \\
189 \pm 20.1\end{array}$ & $\begin{array}{c}884.2 \pm 252.4^{\mathrm{b}} \\
1158 \pm 51.0^{\mathrm{b}}\end{array}$ & $\begin{array}{c}742.4 \pm 93.3^{b} \\
1030 \pm 122.8^{b}\end{array}$ \\
\hline Fructosamine $(\mu \mathrm{mol} / \mathrm{l})$ & $\begin{array}{l}18 \\
24\end{array}$ & $\begin{array}{l}387.5 \pm 32.5 \\
323.0 \pm 14.1\end{array}$ & $\begin{array}{l}307.0 \pm 23.3 \\
274.0 \pm 6.9\end{array}$ & $\begin{array}{l}403.3 \pm 64.8 \\
470.8 \pm 28.2^{b}\end{array}$ & $\begin{array}{l}416.0 \pm 29.9^{b} \\
429.3 \pm 37.5^{b}\end{array}$ \\
\hline Total cholesterol (mg/dl) & $\begin{array}{l}18 \\
24\end{array}$ & $\begin{array}{l}71.5 \pm 2.5 \\
83.5 \pm 3.8\end{array}$ & $\begin{array}{l}71.0 \pm 3.2 \\
87.5 \pm 2.9\end{array}$ & $\begin{array}{l}273.3 \pm 41.2^{\mathrm{b}} \\
190.5 \pm 25.9^{\mathrm{b}}\end{array}$ & $\begin{array}{l}318.4 \pm 27.0^{\mathrm{b}} \\
204.5 \pm 33.6^{\mathrm{b}}\end{array}$ \\
\hline HDL-cholesterol (mg/dl) & $\begin{array}{l}18 \\
24\end{array}$ & $\begin{array}{l}45.5 \pm 7.5 \\
38.5 \pm 5.6\end{array}$ & $\begin{array}{l}53.8 \pm 2.7 \\
52.8 \pm 3.1\end{array}$ & $\begin{array}{l}110.7 \pm 6.8^{a} \\
111.8 \pm 9.8^{b}\end{array}$ & $\begin{array}{l}131.0 \pm 19.4^{b} \\
106.8 \pm 14.9^{b}\end{array}$ \\
\hline Triglyceride (mg/dl) & $\begin{array}{l}18 \\
24\end{array}$ & $\begin{array}{l}89.0 \pm 20.0 \\
71.2 \pm 5.2\end{array}$ & $\begin{array}{c}103.0 \pm 14.1 \\
88.3 \pm 2.7\end{array}$ & $\begin{array}{l}116.3 \pm 30.3 \\
152.0 \pm 10.6^{b}\end{array}$ & $\begin{array}{l}130.0 \pm 19.6 \\
161.0 \pm 27.2^{\mathrm{b}}\end{array}$ \\
\hline
\end{tabular}

${ }^{\mathrm{a}} \mathrm{p}<0.05$ versus $\mathrm{db} / \mathrm{m}$ mice receiving identical exposure. ${ }^{\mathrm{b}} \mathrm{p}<0.01$ versus $\mathrm{db} /+\mathrm{m}$ mice receiving identical exposure. Values are the mean $\pm \mathrm{SEM}$ in each group.

\section{Materials and methods}

Animals. Five-week old female C57BL/KsJ-db/db Jcl (db/db) mice ( $\mathrm{n}=24)$ weighing 23.6-29.1 $\mathrm{g}$ and $\mathrm{C} 57 \mathrm{BL} / \mathrm{KsJ}-\mathrm{db} /+\mathrm{m} \mathrm{Jcl}$ $(\mathrm{db} /+\mathrm{m})$ mice $(\mathrm{n}=16)$ weighing $15.5-20.4 \mathrm{~g}$ as normal controls were supplied by Japan Clea Co. (Tokyo, Japan). The mice were housed in an animal facility that was maintained at 24$26^{\circ} \mathrm{C}$ with $55-75 \%$ humidity and a $14: 10$-h light:dark cycle; they were fed (Meiji Seika Kaisha Ltd., Saitama, Japan) and given water ad libitum. The studies followed the National Institutes of Health guidelines for the experimental use of animals. The Institutional Review Board approved all animal studies.

Collection of DEP. A 4JB1-type, light-duty, four-cyclinder, 2.74-L, Isuzu diesel engine (Isuzu Automobile Co.,Tokyo, Japan) under computer control was connected to a dynamometer (Meiden-sha, Tokyo Japan). The engine was operated on standard diesel fuel at $1500 \mathrm{rpm}$ under a road of 10 torque $(\mathrm{kg} / \mathrm{m})$. DEP were collected as previously described (19). The mass median aerodynamic diameter of DEP was $0.4 \mu \mathrm{m}$ by an Anderson Air Sampler (Shibata Science Technology, Tokyo, Japan). Most of the particles were globular in shape.

Study protocol. $\mathrm{Db} / \mathrm{db}$ mice and $\mathrm{db} /+\mathrm{m}$ mice were randomly divided into four experimental groups: the $\mathrm{db} / \mathrm{db}$-vehicle group, the $\mathrm{db} / \mathrm{db}$-DEP group, the $\mathrm{db} /+\mathrm{m}$-vehicle group, and the $\mathrm{db} /+\mathrm{m}-\mathrm{DEP}$ group. The vehicle groups intratracheally received $100 \mu 1$ of phosphate-buffered saline at $\mathrm{pH} 7.4$ containing $0.05 \%$ Tween-80 every two weeks. The DEP groups intratracheally received $100 \mu \mathrm{g}$ DEP (20) in the same vehicle every two weeks. The DEP suspension was sonicated for 3 min with an ultrasonic disrupter (UD-201, Tomy Seiko, Tokyo, Japan). The mice were anesthetized with $4 \%$ halothane (Takeda Chemical Industries Ltd., Osaka, Japan) and intratracheally administered DEP or vehicle for 12 or 18 weeks (7 or 9 times). Body weights were continuously measured every week.
At 18 or 24 weeks of age, the animals were exsanguinated under deep anesthesia with diethyl ether, body weights and the weights of the liver, kidney, and heart were measured. Routine laboratory examinations including total protein, albumin, blood urea nitrogen, uric acid, creatinine, glucose, fructosamine, aspartate aminotransferase (AST), alanine aminotransferase (ALT), total cholesterol, HDL cholesterol, and triglyceride were conducted on plasma. The livers were fixed in $10 \%$ neutral phosphate-buffered formalin for histological examinations.

Histology and quantitative analysis. The livers were embedded in paraffin. Three-micrometer sections were affixed to slides, deparaffinized, and stained with hematoxylin and eosin. Tissue sections of the liver from the mice at 24 weeks of age were quantitatively examined by A.S. and M.T., and the magnitude of fatty change was graded in a blinded fashion. The degree of fatty change was performed according to modified criteria based on Brunt et al (scored from 0 to 5: 0, none; 1, <20\%; 2 , $20-40 \%$; 3, 40-60\%; 4, 60-80\%; 5, >80\%) (21).

Immunohistochemistry. The generation of hexanoyl-lysine (HEL) adduct in the liver from mice at 18 or 24 weeks of age was detected by immunohistochemistry using anti-HEL monoclonal antibody (supplied by University of Hyogo, Hyogo, Japan). In brief, deparaffinized slides were blocked with $10 \%$ goat serum for $1 \mathrm{~h}$. After blocking, anti-HEL antibody (1:500) was incubated with sections for $1 \mathrm{~h}$ at room temperature, followed by incubation of a biotinylated secondary antibody and streptavidin-peroxidase conjugate. Then, the slides were incubated with 3-amino, 9-ethylcarbazole chromogen, and counterstained with hematoxylin using an AutoProbe III kit (Biomedia, Foster City, CA, USA).

Statistical analysis. Data were reported as mean \pm SEM. Differences among groups were determined using analysis of variance (Stat view version 4.0; Abacus Concepts, Inc., Berkeley, CA). If differences among groups were significant 


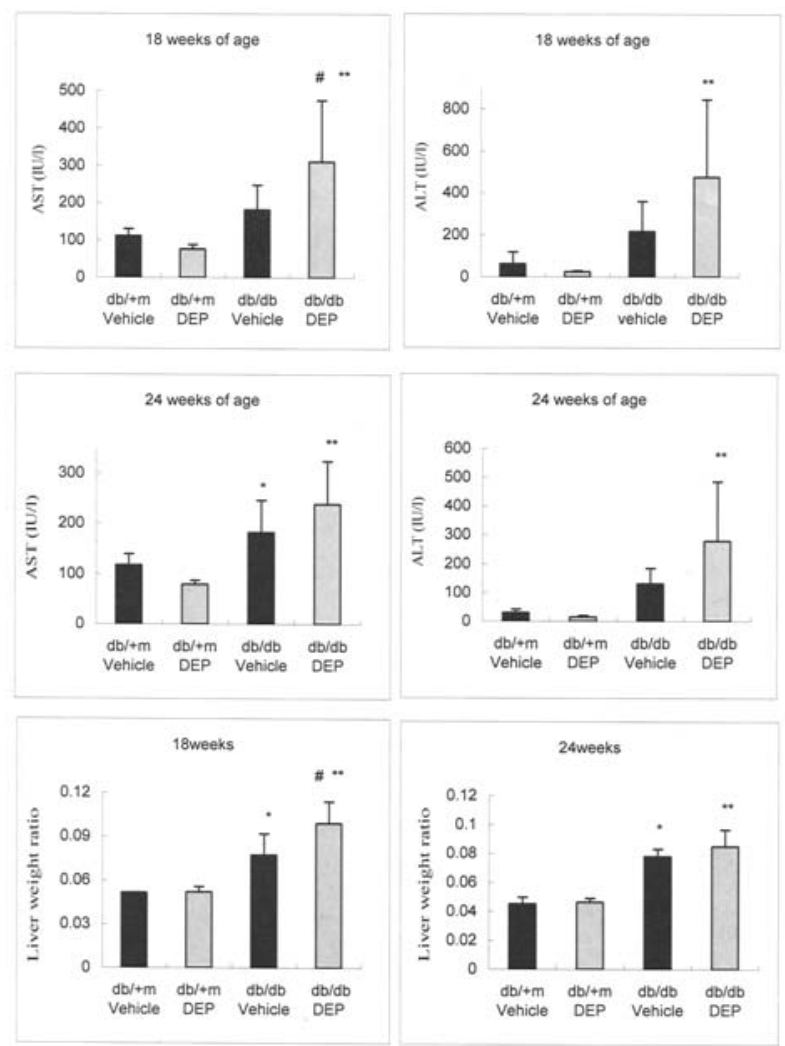

Figure 1. Aspartate aminotransferase, alanine aminotransferase, and liver weight under pulmonary exposure to vehicle or DEP. Mice were intratracheally administered DEP or vehicle every two weeks. Blood samples were collected after exsanguination, the plasma levels of aspartate aminotransferase (AST) and alanine aminotransferase (ALT) were measured in diabetic $(\mathrm{db} / \mathrm{db})$ mice and nondiabetic $(\mathrm{db} / \mathrm{+m})$ mice at 18 or 24 weeks of age. Body weights and the weights of the liver were measured. A, plasma levels of AST at 18 weeks of age; B, plasma levels of ALT at 18 weeks of age; C, plasma levels of AST at 24 weeks of age; D, plasma levels of ALT at 24 weeks of age; E, the ratio of liver weights to body weights at 18 weeks of age; $F$, the ratio of liver weights to body weights at 24 weeks of age. ${ }^{*} \mathrm{p}<0.05$ versus $d b /+m$ mice receiving identical exposure. ${ }^{* *} \mathrm{p}<0.01$ versus $\mathrm{db} / \mathrm{m}$ mice receiving identical exposure. ${ }^{*} \mathrm{p}<0.05$ versus vehicle exposure in the identical strains. Values are the mean \pm SEM in each group.

$(\mathrm{p}<0.05$ or 0.01$)$, Fisher's protected least significant difference test was used to distinguish between pairs of groups.

\section{Results}

Effects of pulmonary exposure to DEP on aminotransferase levels. The levels of AST and ALT (Fig. 1A-D) were greater in the $\mathrm{db} / \mathrm{db}$ mice than in the $\mathrm{db} /+\mathrm{m}$ mice under exposure to either DEP or vehicle $(\mathrm{p}<0.01 \mathrm{db} /+\mathrm{m}-\mathrm{DEP}$ versus $\mathrm{db} / \mathrm{db}-\mathrm{DEP}$ for AST and ALT at 18 and 24 weeks of age, $p<0.05: \mathrm{db} /+\mathrm{m}-$ vehicle versus $\mathrm{db} / \mathrm{db}$-vehicle for AST at 24 weeks of age). In the $\mathrm{db} /+\mathrm{m}$ mice, the levels of AST and ALT were not significantly different between vehicle exposure and DEP exposure. In the $\mathrm{db} / \mathrm{db}$ mice, however, DEP exposure enhanced the levels of AST ( $<<0.05$ at 18 weeks of age) and ALT (N.S.) as compared with vehicle exposure.

Effects of pulmonary exposure to DEP on biochemical parameters. In overall trends, the levels of glucose $(\mathrm{p}<0.01$ : $\mathrm{db} /+\mathrm{m}$ mice versus $\mathrm{db} / \mathrm{db}$ mice receiving identical exposure),

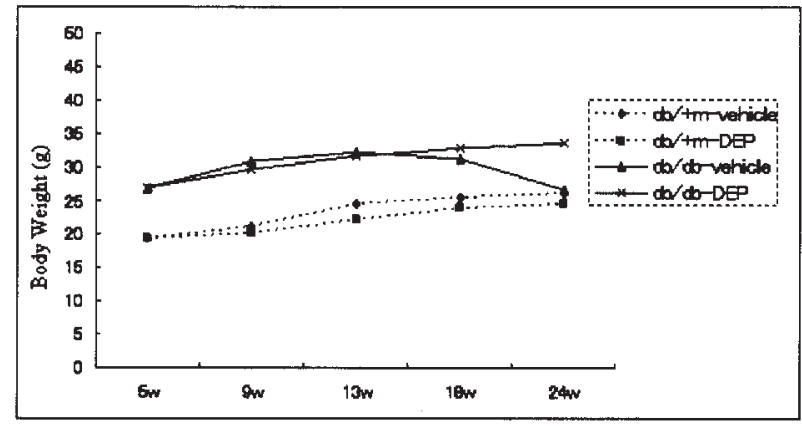

Figure 2. Effects of pulmonary exposure to DEP on body weight. Mice were intratracheally administered DEP or vehicle every two weeks for 12 or 18 weeks. Body weights were continuously measured every week.

fructosamine $(\mathrm{p}<0.01: \mathrm{db} /+\mathrm{m}-\mathrm{DEP}$ versus $\mathrm{db} / \mathrm{db}-\mathrm{DEP}, \mathrm{p}<0.01$ : $\mathrm{db} /+\mathrm{m}$-vehicle versus $\mathrm{db} / \mathrm{db}$-vehicle at 24 weeks of age), total cholesterol $(\mathrm{p}<0.01: \mathrm{db} /+\mathrm{m}$ mice versus $\mathrm{db} / \mathrm{db}$ mice receiving identical exposure), HDL cholesterol $(\mathrm{p}<0.01: \mathrm{db} /+\mathrm{m}-\mathrm{DEP}$ versus $\mathrm{db} / \mathrm{db}$-DEP and $\mathrm{db} /+\mathrm{m}$-vehicle versus $\mathrm{db} / \mathrm{db}$-vehicle at 24 weeks of age, $\mathrm{p}<0.05: \mathrm{db} /+\mathrm{m}$-vehicle versus $\mathrm{db} / \mathrm{db}$-vehicle at 18 weeks of age), and triglyceride $(\mathrm{p}<0.01: \mathrm{db} /+\mathrm{m}$ mice versus $\mathrm{db} / \mathrm{db}$ mice receiving identical exposure at 24 weeks of age) were greater in the $\mathrm{db} / \mathrm{db}$ mice than in the $\mathrm{db} /+\mathrm{m}$ mice (Table I). DEP exposure did not enhance the levels of glucose, fructosamine, total cholesterol, HDL cholesterol, and triglyceride as compared to vehicle exposure in both types of mice.

The levels of total protein, albumin, blood urea nitrogen, uric acid, and creatine were not significantly different between the experimental groups (data not shown).

Effects of pulmonary exposure to DEP on body weight and liver weight. Overall, $\mathrm{db} / \mathrm{db}$ mice eventually developed more severe obesity than $\mathrm{db} /+\mathrm{m}$ mice under exposure either to DEP or vehicle (Fig. 2). However, DEP exposure did not significantly enhance body weight as compared to vehicle exposure in both types of mice.

The ratio of liver weight to body weight (Fig. 1E and F) was significantly greater in the $\mathrm{db} / \mathrm{db}$ mice than in the $\mathrm{db} /+\mathrm{m}$ mice under exposure to either DEP ( $<<0.01$ at 18 and 24 weeks of age) or vehicle ( $<<0.05$ at 18 and 24 weeks of age). In the $\mathrm{db} /+\mathrm{m}$ mice, the ratio was not significantly different between vehicle exposure and DEP exposure. In the $\mathrm{db} / \mathrm{db}$ mice, however, DEP exposure significantly enhanced the ratio as compared with vehicle exposure $(\mathrm{p}<0.05$ at 18 weeks).

Effects of DEP on fatty change in the liver. The magnitude of fatty change in the liver was greater in the $\mathrm{db} / \mathrm{db}$ mice (Fig. 3C, D, G, H) than in the db/+m mice (Fig. 3A, B, E, F) under exposure to either DEP or vehicle at 18 and 24 weeks of age. In the $\mathrm{db} /+\mathrm{m}$ mice, the magnitude of fatty change in the liver was not different between vehicle exposure (Fig. 3A and E) and DEP exposure (Fig. 3B and F) at 18 (Fig. 3A and B) and 24 weeks (Fig. 3E and F) of age. In the $\mathrm{db} / \mathrm{db}$ mice, however, DEP exposure (Fig. 3D and $\mathrm{H}$ ) enhanced the magnitude of fatty change as compared with vehicle exposure (Fig. 3C and G) at 18 (Fig. 3C and D) and 24 (Fig. 3G and H) weeks of age. The magnitude of fatty change in the liver was scored 

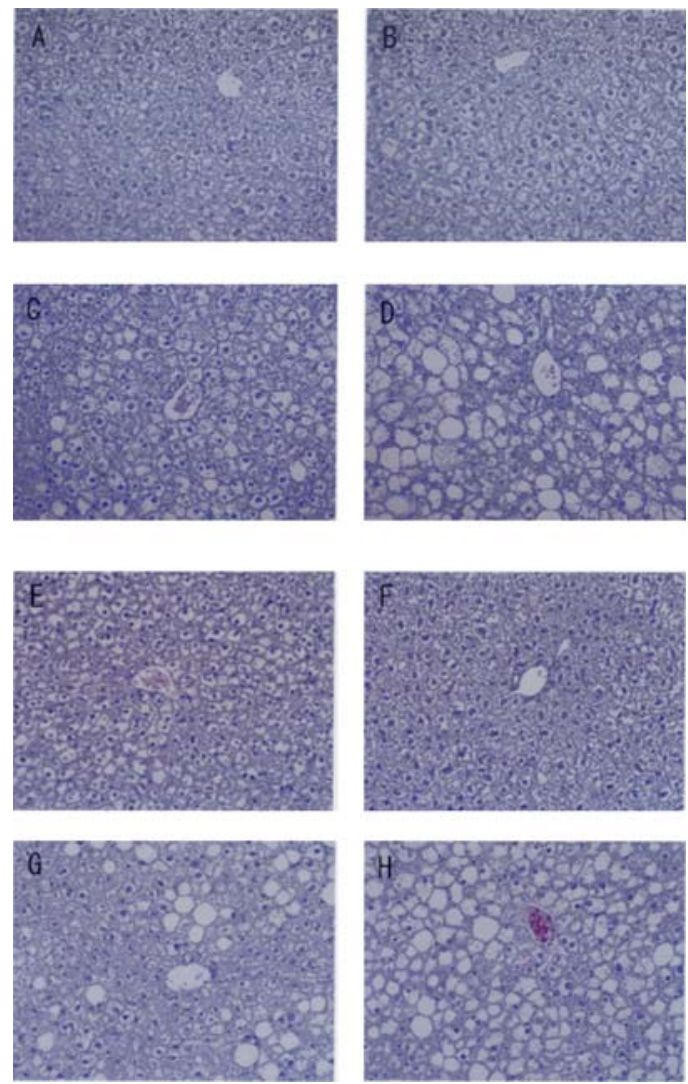

Figure 3. Effects of pulmonary exposure to DEP on fatty change in the liver histology. Mice were intratracheally administered DEP or vehicle every two weeks for 12 or 18 weeks. The livers were fixed and embedded in paraffin. The sections were stained with hematoxylin and eosin. $\mathrm{A}, \mathrm{db} / \mathrm{m}$-vehicle group; $\mathrm{B}, \mathrm{db} /+\mathrm{m}$-DEP group; $\mathrm{C}, \mathrm{db} / \mathrm{db}$-vehicle group; $\mathrm{D}, \mathrm{db} / \mathrm{db}$ - DEP group at 18 weeks of age. E, db/+m-vehicle group; F, db/+m-DEP group; G, db/dbvehicle group; $\mathrm{H}, \mathrm{db} / \mathrm{db}-\mathrm{DEP}$ group at 24 weeks of age. Original magnification $\mathrm{x} 400$.

Table II. Quantitative analysis for fatty change.

\begin{tabular}{lcc}
\hline Strain & Exposure & Score of fatty change \\
\hline $\mathrm{db} / \mathrm{m}$ & vehicle & $0.5 \pm 0.289$ \\
$\mathrm{db} / \mathrm{m}$ & DEP & $1.0 \pm 0.577$ \\
$\mathrm{db} / \mathrm{db}$ & vehicle & $2.6 \pm 0.927^{\mathrm{a}}$ \\
$\mathrm{db} / \mathrm{db}$ & DEP & $4.0 \pm 0.577^{\mathrm{a}}$
\end{tabular}

${ }^{\mathrm{a}} \mathrm{p}<0.05$ versus $\mathrm{db} /+\mathrm{m}$ mice receiving identical exposure. Values are the mean \pm SEM in each group.

in each specimen at 24 weeks of age. The scores of fatty change were significantly greater in the $\mathrm{db} / \mathrm{db}$ mice than in the $\mathrm{db} /+\mathrm{m}$ mice receiving exposure to vehicle or DEP $(\mathrm{p}<0.05$; Table II). In the $\mathrm{db} / \mathrm{db}$ mice, pulmonary exposure to DEP enhanced the magnitude of fatty change as compared to that to vehicle, although it didn't reach statistical significance.

Effects of pulmonary exposure to DEP on HEL formation. The staining for HEL was not apparent under exposure to either
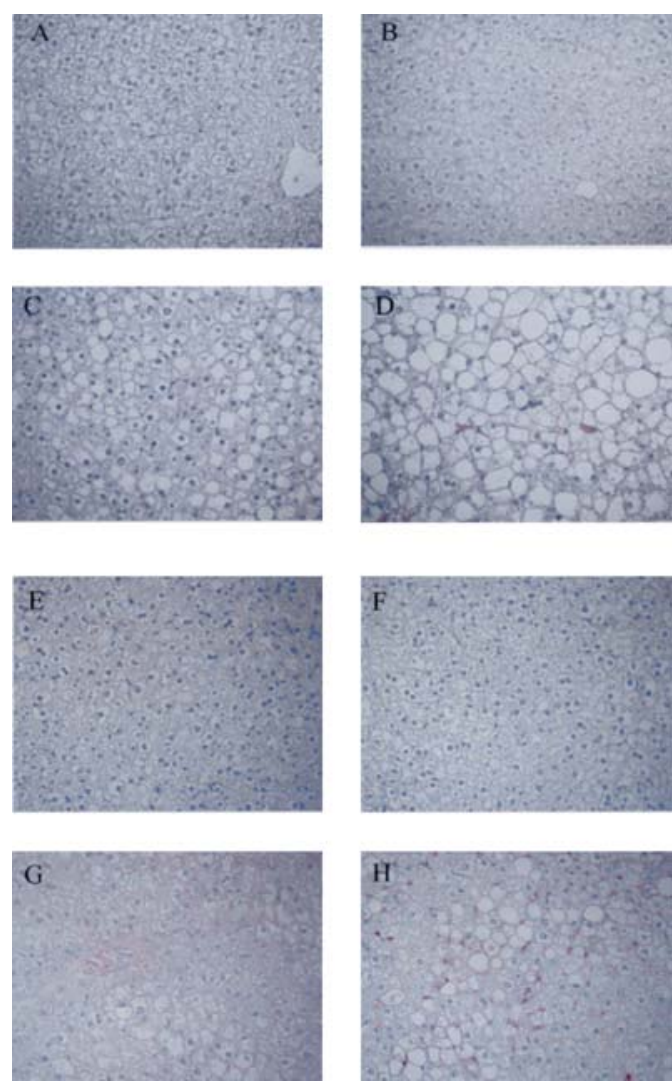

Figure 4. Effects of pulmonary exposure to DEP on the oxidative stress in the liver. Mice were intratracheally administered DEP or vehicle every two weeks for 12 or 18 weeks. The livers were fixed and embedded in paraffin. In the sections, the generation of hexanoyl-lysine (HEL) adduct was detected by immunohistochemistry using anti-HEL antibody. A, db/+m-vehicle group; $\mathrm{B}, \mathrm{db} /+\mathrm{m}$-DEP group; $\mathrm{C}, \mathrm{db} / \mathrm{db}$-vehicle group; $\mathrm{D}, \mathrm{db} / \mathrm{db}-\mathrm{DEP}$ group at 18 weeks of age; E, db/+m-vehicle group; F, db/+m-DEP group; $\mathrm{G}, \mathrm{db} / \mathrm{db}$ vehicle group; $\mathrm{H}, \mathrm{db} / \mathrm{db}-\mathrm{DEP}$ group at 24 weeks of age. Original magnification $\mathrm{x} 400$.

vehicle or DEP in the $\mathrm{db} /+\mathrm{m}$ mice (Fig. $4 \mathrm{~A}$ and B) at 18 or 24 weeks (Fig. 4E and F) of age. Positive staining for HEL was slightly observed in the livers of $\mathrm{db} / \mathrm{db}$ mice exposed to DEP at 18 weeks of age (Fig. 4D), but not in those exposed to vehicle (Fig. 4C). At 24 weeks of age, however, positive staining for HEL was apparent in the livers of the $\mathrm{db} / \mathrm{db}$ mice (Fig. 4G and $\mathrm{H}$ ), which was far more prominent under exposure to DEP (Fig. 4H)

\section{Discussion}

The present study has shown that pulmonary exposure to DEP, particulate air pollutants, enhances fatty change in the livers of diabetic obese mice. The enhancement is concomitant with oxidative stress in the liver.

It has been reported that ambient PM containing elementary carbon, sulfate, heavy metals, and organic compounds can cause and enhance cardiopulmonary diseases $(22,23)$. DEP form a large constituent of ambient urban PM. Inhalation or intratracheal instillation of DEP or the components of DEP has been shown to enhance lung inflammation and asthma $(20,24)$, and to deteriorate biological cardiovascular functions (25). On the other hand, cardiovascular disorders are critical 
participants in life habit diseases. Diabetes mellitus is another typical life habit disease and is characterized by complicated cardiovascular risk factors (26-28). In epidemiological studies, individuals with diabetes mellitus have higher risk for death from exposure to polluted ambient air $(11,12)$. However, few experimental studies have elucidated the association between ambient air pollution and diabetes mellitus. We have previously described that nitrogen dioxide air pollution near ambient levels is an atherogenic risk primarily in obese diabetic subjects (29) .

$\mathrm{db} / \mathrm{db}$ mice develop obesity, hyperglycemia, hyperlipemia, and insulin resistance, which is a good animal model for human type 2 diabetes mellitus, as do the corresponding control mice $(\mathrm{db} /+\mathrm{m})$. Also in the present study, $\mathrm{db} / \mathrm{db}$ mice developed obesity, hyperglycemia, hyperlipemia, and fatty change in the liver, whereas the control $\mathrm{db} /+\mathrm{m}$ mice did not. Thus, $\mathrm{db} / \mathrm{db}$ mice should be useful for determination of the effects of air pollution on fatty change in the liver of type 2 diabetic obese subjects.

In the present study, pulmonary exposure of obese diabetic mice to DEP enhanced the levels of AST, ALT, the ratio of liver weight, and the magnitude of fatty change of the liver in histology as compared to that to vehicle. To our knowledge, this should be the first report that pulmonary exposure to DEP, air pollutants, can aggravate fatty change in the liver in type 2 diabetic subjects. Interestingly, pulmonary exposure of normal mice to DEP did not affect the liver as compared to vehicle exposure. Thus, the present results can, at least partly, provide experimental evidence to the previous epidemiological reports that diabetic subjects are susceptible populations to PM air pollution.

Our previous researches have shown that pulmonary exposure to DEP induces the expression of Cyp1A1 (30) and ROS $(31,32)$ in the lung, which might play an important role in the present aggravation of fatty change by DEP. DEP contain carbonaceous nuclei which absorb a vast number of organic compounds, such as polycyclic aromatic hydrocarbons, nitropolycyclic aromatic hydrocarbons, heterocyclics, quinones, aldehydes, and aliphatic hydrocarbons (33-35). Particularly, some quinones can generate ROS (36), including superoxide, hydrogen peroxide, and ultimately hydroxyl radical, resulting in biological damage. Cyp enzymes, which can be induced by DEP exposure, are known to produce ROS (37). Cyp1A1 has been reported to be an active Cyp source of superoxide production (38). Also, Cyp2E1 is an enzyme that is closely related to oxidative stress developed in NAFLD patients with steatosis $(39,40)$. In the present study, however, pulmonary exposure to DEP did not enhance the expression of Cyp1A1 and Cyp2E1 in the livers of both types of mice (data not shown).

On the other hand, oxidative stress in mitochondria is considered to play an important role in the pathogenesis of NAFLD. Mitochondria are involved in fatty acid B-oxidation and in oxidative phosphorylation and are an important source of ROS. The increased production of ROS by mitochondria is known to cause lipid peroxidation. Lipid peroxidation products impair the flow of electrons along the respiratory chain, which may cause overreduction of respiratory chain components, and result in further increasing mitochondrial ROS formation and lipid peroxidation (41). It has been reported that DEP decreased the mitochondrial membrane potential and increased ROS, followed by cytochrome c release and inner mitochondria membrane damage. The DEP-induced mitochondrial damage could be involved in the present enhancing effects on NAFLD, especially in the enhancing effects on oxidative stress. HEL used in this study is a lipid peroxide-modified lysine residue, which is a marker of oxidative stress at an earlier stage compared with malondialdeyde (42). In the present study, extensive HEL staining was observed only in $\mathrm{db} / \mathrm{db}$ mice, which was far more enhanced by exposure to DEP than to vehicle. These results suggest that lipid peroxidation or oxidative stress is responsible, at least partly, for the enhancement of NAFLD change in $\mathrm{db} / \mathrm{db}$ mice after DEP exposure.

The present study is the first demonstration that pulmonary exposure to DEP can cause oxidative stress in the liver, a remote organ from the direct site of exposure. It is possible that ROS, lipid peroxides, or inflammatory cytokines originating in the lung reach the liver. It is also possible that DEP or soluble components in DEP, including organic chemicals or metals, can move from the lung to the liver via systemic circulation.

In conclusion, pulmonary exposure to DEP aggravates fatty change in the liver of subjects with type 2 diabetes mellitus with obesity possibly via oxidative stress. Future epidemiological studies should focus on the effects of air pollution on NAFLD in diabetic obese subjects.

\section{Acknowledgements}

This study was supported by a grant (no. 15310030) for scientific research from the Ministry of Education, Science and Culture of Japan. The authors thank Miho Sakurai, Naoko Ueki and Emiko Shimada for their assistance throughout the study.

\section{References}

1. Mar TF, Norris GA, Koenig JQ and Larson TV: Associations between air pollution and mortality in Phoenix, 1995-1997. Environ Health Perspect 108: 347-353, 2000.

2. Schwartz J: Air pollution and blood markers of cardiovascular risk. Environ Health Perspect 109 (suppl 3): 405-409, 2001.

3. Pope CA III and Kanner RE: Acute effects of PM10 pollution on pulmonary function of smokers with mild to moderate chronic obstructive pulmonary disease. Am Rev Respir Dis 147: 1336-1340, 1993.

4. Sunyer J, Schwartz J, Tobias A, Macfarlane D, Garcia J and Anto JM: Patients with chronic obstructive pulmonary disease are at increased risk of death associated with urban particle air pollution: a case-crossover analysis. Am J Epidemiol 151: 50-56, 2000.

5. King H, Aubert RE and Herman WH: Global burden of diabetes, 1995-2025: prevalence, numerical estimates, and projections. Diabetes Care 21: 1414-1431, 1998.

6. The effect of intensive treatment of diabetes on the development and progression of long-term complications in insulin-dependent diabetes mellitus. The Diabetes Control and Complications Trial Research Group. N Engl J Med 329: 977-986, 1993.

7. Foster KJ, Griffith AH, Dewbury K, Price CP and Wright R: Liver disease in patients with diabetes mellitus. Postgrad Med J 56: 767-772, 1980.

8. Leevy CM: Fatty liver: a study of 270 patients with biopsy proven fatty liver and review of the literature. Medicine 41: 249-276, 1962.

9. Silverman JF, Pories WJ and Caro JF: Liver pathology in diabetes mellitus and morbid obesity. Clinical, pathological, and biochemical considerations. Pathol Annu 24: 275-302, 1989.

10. Stone BG and Van Thiel DH: Diabetes mellitus and the liver. Semin Liver Dis 5: 8-28, 1985. 
11. Goldberg MS, Burnett RT, Bailar JC III, Brook J, Bonvalot Y, Tamblyn R, Singh R, Valois MF and Vincent R: The association between daily mortality and ambient air particle pollution in Montreal, Quebec. 2. Cause-specific mortality. Environ Res 86: 26-36, 2001.

12. Goldberg MS, Burnett RT, Yale JF, Valois MF and Brook JR: Associations between ambient air pollution and daily mortality among persons with diabetes and cardiovascular disease. Environ Res 100: 255-267, 2006.

13. Hiura TS, Li N, Kaplan R, Horwitz M, Seagrave JC and Nel AE: The role of a mitochondrial pathway in the induction of apoptosis by chemicals extracted from diesel exhaust particles. J Immunol 165: 2703-2711, 2000.

14. Sagai M, Saito H, Ichinose T, Kodama M and Mori Y: Biological effects of diesel exhaust particles. I. In vitro production of superoxide and in vivo toxicity in mouse. Free Radic Biol Med 14: 37-47, 1993

15. Kumagai Y, Arimoto T, Shinyashiki M, Shimojo N, Nakai Y, Yoshikawa T and Sagai M: Generation of reactive oxygen species during interaction of diesel exhaust particle components with NADPH-cytochrome P450 reductase and involvement of the bioactivation in the DNA damage. Free Radic Biol Med 22: 479-487, 1997.

16. Nishikawa T, Edelstein D and Brownlee M: The missing link: a single unifying mechanism for diabetic complications. Kidney Int (suppl 77): S26-S30, 2000.

17. Rosen P, Nawroth PP, King G, Moller W, Tritschler HJ and Packer L: The role of oxidative stress in the onset and progression of diabetes and its complications: a summary of a Congress Series sponsored by UNESCO-MCBN, the American Diabetes Association and the German Diabetes Society. Diabetes Metab Res Rev 17: 189-212, 2001.

18. Clark JM, Brancati FL and Diehl AM: Nonalcoholic fatty liver disease. Gastroenterology 122: 1649-1657, 2002.

19. Sagai M, Furuyama A and Ichinose T: Biological effects of diesel exhaust particles (DEP). III. Pathogenesis of asthma like symptoms in mice. Free Radic Biol Med 21: 199-209, 1996.

20. Takano H, Yoshikawa T, Ichinose T, Miyabara Y, Imaoka K and Sagai M: Diesel exhaust particles enhance antigen-induced airway inflammation and local cytokine expression in mice. Am J Respir Crit Care Med 156: 36-42, 1997.

21. Brunt EM, Janney CG, Di Bisceglie AM, Neuschwander-Tetri BA and Bacon BR: Nonalcoholic steatohepatitis: a proposal for grading and staging the histological lesions. Am J Gastroenterol 94: 2467-2474, 1999

22. Seaton A, MacNee W, Donaldson K and Godden D: Particulate air pollution and acute health effects. Lancet 345: 176-178, 1995.

23. Ye F, Piver WT, Ando M and Portier CJ: Effects of temperature and air pollutants on cardiovascular and respiratory diseases for males and females older than 65 years of age in Tokyo, July and August 1980-1995. Environ Health Perspect 109: 355-359, 2001.

24. Takano H, Ichinose T, Miyabara Y, Shibuya T, Lim HB, Yoshikawa T and Sagai M: Inhalation of diesel exhaust enhances allergen-related eosinophil recruitment and airway hyperresponsiveness in mice. Toxicol Appl Pharmacol 150: 328-337, 1998.

25. Yokota S, Furuya M, Seki T, Marumo H, Ohara N and Kato A: Delayed exacerbation of acute myocardial ischemia/reperfusioninduced arrhythmia by tracheal instillation of diesel exhaust particles. Inhal Toxicol 16: 319-331, 2004.

26. Gerritsen J, Dekker JM, TenVoorde BJ, Bertelsmann FW, Kostense PJ, Stehouwer CD, Heine RJ, Nijpels G, Heethaar RM and Bouter LM: Glucose tolerance and other determinants of cardiovascular autonomic function: the Hoorn Study. Diabetologia 43: 561-570, 2000.
27. Singh JP, Larson MG, O'Donnell CJ, Wilson PF, Tsuji H, Lloyd-Jones DM and Levy D: Association of hyperglycemia with reduced heart rate variability (The Framingham Heart Study). Am J Cardiol 86: 309-312, 2000.

28. Stec JJ, Silbershatz H, Tofler GH, Matheney TH, Sutherland P, Lipinska I, Massaro JM, Wilson PF, Muller JE and D'Agostino RB Sr: Association of fibrinogen with cardiovascular risk factors and cardiovascular disease in the Framingham Offspring Population. Circulation 102: 1634-1638, 2000.

29. Takano H, Yanagisawa R, Inoue K, Shimada A, Ichinose T, Sadakane K, Yoshino S, Yamaki K, Morita M and Yoshikawa T: Nitrogen dioxide air pollution near ambient levels is an atherogenic risk primarily in obese subjects: a brief communication. Exp Biol Med 229: 361-364, 2004.

30. Takano H, Yanagisawa R, Ichinose T, Sadakane K, Inoue K, Yoshida S, Takeda K, Yoshino S, Yoshikawa T and Morita M: Lung expression of cytochrome P450 1A1 as a possible biomarker of exposure to diesel exhaust particles. Arch Toxicol 76: 146-151, 2002.

31. Lim HB, Ichinose T, Miyabara Y, Takano H, Kumagai Y, Shimojyo N, Devalia JL and Sagai M: Involvement of superoxide and nitric oxide on airway inflammation and hyperresponsiveness induced by diesel exhaust particles in mice. Free Radic Biol Med 25: 635-644, 1998.

32. Sanbongi C, Takano H, Osakabe N, Sasa N, Natsume M, Yanagisawa R, Inoue K, Kato Y, Osawa T and Yoshikawa T: Rosmarinic acid inhibits lung injury induced by diesel exhaust particles. Free Radic Biol Med 34: 1060-1069, 2003.

33. Draper WM: Quantitation of nitro and dinitropolycyclic aromatic hydrocarbons in diesel exhaust particulate matter. Chemosphere 15: 437-447, 1986.

34. Schuetzle D: Sampling of vehicle emissions for chemical analysis and biological testing. Environ Health Perspect 47: 65-80, 1983.

35. Schuetzle D and Lewtas J: Bioassay-directed chemical analysis in environmental research. Anal Chem 58: 1060A-1075A, 1986.

36. Bolton JL, Trush MA, Penning TM, Dryhurst G and Monks TJ: Role of quinones in toxicology. Chem Res Toxicol 13: 135-160, 2000.

37. Yamazaki H, Hatanaka N, Kizu R, Hayakawa K, Shimada N, Guengerich FP, Nakajima M and Yokoi T: Bioactivation of diesel exhaust particle extracts and their major nitrated polycyclic aromatic hydrocarbon components, 1-nitropyrene and dinitropyrenes, by human cytochromes P450 1A1, 1A2, and 1B1. Mutat Res 472: 129-138, 2000.

38. Puntarulo S and Cederbaum AI: Production of reactive oxygen species by microsomes enriched in specific human cytochrome P450 enzymes. Free Radic Biol Med 24: 1324-1330, 1998.

39. Videla LA, Rodrigo R, Orellana M, Fernandez V, Tapia G, Quinones L, Varela N, Contreras J, Lazarte R, Csendes A, Rojas J, Maluenda F, Burdiles P, Diaz JC, Smok G, Thielemann L and Poniachik J: Oxidative stress-related parameters in the liver of non-alcoholic fatty liver disease patients. Clin Sci 106: 261-268, 2004

40. Weltman MD, Farrell GC, Hall P, Ingelman-Sundberg M and Liddle C: Hepatic cytochrome P450 2E1 is increased in patients with nonalcoholic steatohepatitis. Hepatology 27: 128-133, 1998.

41. Pessayre D, Berson A, Fromenty B and Mansouri A: Mitochondria in steatohepatitis. Semin Liver Dis 21: 57-69, 2001

42. Kato Y, Mori Y, Makino Y, Morimitsu Y, Hiroi S, Ishikawa T and Osawa T: Formation of Nepsilon-(hexanonyl)lysine in protein exposed to lipid hydroperoxide. A plausible marker for lipid hydroperoxide-derived protein modification. J Biol Chem 274: 20406-20414, 1999. 